and intermational. The bulk of the tables is based on analyses of food samples carried out by the authors themselves, the results being given, for the main constituents, to the first decimal place. While such figures are, of course, accurate with respect to the samples analysed, they are not necessarily fully representative of the foods in question. Users of the tables should not forget that the composition of fresh foods varies widely even when variety and growing and harvesting conditions are uniform. Change in water content, for example, will obviously alter the whole composition of the food. All food composition tables, however carefully prepared, can in effect serve only as a guide in calculating the values of foods and meals. JOYCE DOUGHTY

\section{FREE RADICAL TRAPPING}

Formation and Trapping of Free Radicals

Edited by Arnold M. Bass and H. P. Broida. Pp. xvi+522. (New York: Academic Press, Inc.; London: Academic Press, Inc. (London), Ltd., 1960.) 16 dollars.

AOMS and free radicals, which normally react rapidly with surrounding molecules, can be "trapped' in inert solids; if, for example, solutions in organic glasses are photolysed or products from a gas discharge are condensed at low temperatures. Free radicals have long been postulated as reaction intermediates, but only recently have many attempts been made to produce directly detectable concentrations of them in solids. That development has been rapid is shown by the size of this book. In 1954, seven laboratories independently published preliminary reports, their interest being mainly in determination of structures of radicals ; in 1956, because of the slight possibility of production of sufficient concentrations of free radicals for use as rocket fuels, an intensive research programme was started at the National Bureau of Standards in Washington (under the direction of Dr. H. P. Broida).

Now that this burst of activity is over, research will proceed more slowly; this book will provide the background for the necessary period of consolida. tion. It begins with an excellent historical chapter by F. O. Rice, and there follow several chapters on methods of preparation and detection of trapped radicals. This approach, instead of arrangement by substances studied, is not easy to justify in the present state of knowledge and leads to considerable inconvenience-for example, data on trapped nitrogen atoms are scattered through eight of the sixteen chapters. However, it prevents the book from being a collection of research papers, and forces both authors and readers to reconsider the experimental problems of the field; indeed a certain amount of data relevant to the feasibility of trapping radicals appears here for the first time (Chapter 4).

A wide range of related fields and possible applications of free-radical trapping are dealt with in the later chapters. Some of these ("Rocket Propulsion") are highly speculative, others ("Radicals in Biological Processes") contain a great deal of background information and relatively fow results ; a shortening of the book, if accompanied by a reduction in the price, would certainly have been a great advantage. However, the editors' claim that this is a truly interdisciplinary field must be accepted, and among the new research workers for whose reference this book is written the spectroscopist will be glad to find a chapter on X-ray studies, and the biologist an elementary explanation of the application of electron-spin resonance, all in one volume.

B. Brocklehurst

\section{A FRENCH LEXICON OF PLANT FORMATIONS}

Les Formations Végétales et Paysages Ruraux Lexique et Guide Bibliographique. Par G. Plaisance. (Publié avec l'aide du C.N.R.S.). Pp. 418. (Paris : Gauthier-Villars, 1959.) 3,000 francs.

T ANDSCAPE, vegetation types and plant forma1 tions, as caused by factors of climate and soil and modified by man to suit his varied needs of food, pasturage and building, are basic factors in the evolution of languages and the history of civilization. Their ancient popular terminology has so often been the basis of place names and family names, and as such is studied by linguists, historians and geographers. In recent times they have become the special field of the botanical sciences of ecology, plant geography and phytosociology, which have introduced a disconcerting multitude of new words and phrases for the purposes of definition and classification.

To gather together the words and terms of several principal languages and continents for landscape, vegetation types and plant formations, from those of ancient dialects to the jargon of contemporary ecologists, has been the task of the author of this remarkable and fascinating dictionary. In the main Lexique each word, after definition, is given synonyms, examples of derivatives and main bibliographical references. After this there are special indexes of place names and family names derived from such words (for example, Fresnay (frênaie) ; Lafayette (hêtraie)); a trilingual, columnar lexicon for French, German and English terms; independent English and German indexes; another index, of botanical names; a vocabulary of technical terms used in ecology, plant gecgraphy and phytosociology; and, finally, a very extensive bibliography. The work is illustrated with small photographs and a number of maps. The maps of France showing the distribution, for example, of the many different dialect words for hêtraie, beech-wood, originating in fagetum, or of the great variety of words for expressing defrichement, are of absorbing interest.

Naturally, the work is strongest on the French side, and students of other nationalities will soon find defects and omissions, or will criticize the arrangement. I looked in vain, for example, for English 'down' and 'dune', and not enough attention has been given to recent Spanish publications and to Spanish words: for example, pasto, pastizal, prado and pradera, which appear in so many papers of keen, contemporary, Spanish agronomists should have been distinguished.

Nevertheless, every English ecologist and forester -one is tempted to say, every educated personshould examine this book, if only for repeated casual enjoyment and instruction.

N. Y. SANDWTTH 